\title{
Experimental pancreas disease in Atlantic salmon Salmo salar post-smolts induced by salmon pancreas disease virus (SPDV)
}

\author{
M. F. McLoughlin ${ }^{1, *}$, R. T. Nelson ${ }^{1}$, H. M. Rowley ${ }^{1}$, D. I. Cox ${ }^{2}$, A. N. Grant ${ }^{3}$ \\ ${ }^{1}$ Fish Diseases Unit, Veterinary Sciences Division, Department of Agriculture for Northern Ireland, Stormont, \\ Belfast BT4 3SD, Northern Ireland, UK \\ ${ }^{2}$ Marine Harvest McConnell, Lochailort, Inverness-shire PH38 4LZ, Scotland, UK \\ ${ }^{3}$ Marine Harvest McConnell, Farms Office, Blar Mhor Industrial Estate, Fort William PH33 7PT, Scotland, UK
}

\begin{abstract}
Disease-free Atlantic salmon Salmo salar post-smolts (mean weight $87 \mathrm{~g}$ ) were maintained in a flow-through ozone-sterilized sea water system at 12 to $15^{\circ} \mathrm{C}$ and ambient salinity. One hundred fish were intraperitoneally inoculated with $0.1 \mathrm{ml}$ of salmon pancreas disease virus (SPDV) of a titre $10^{7}$ $\mathrm{TCID}_{50} \mathrm{ml}^{-1}$ Fifty fin-clipped uninoculated smolts were placed in-contact in the same tank. One hundred fish were kept in another tank as controls and were inoculated with a lysate from un-infected Chinook salmon embryo (CHSE-214) cell cultures. Blood and tissues for virus isolation, serum neutralisation tests and histological examination were taken at intervals up to 42 days post inoculation (dpi). Virus was re-isolated from SPDV inoculated smolts at 7, 10, 15 and $21 \mathrm{dpi}$ and in-contact fish at 14 and $21 \mathrm{dpi}$. Neutralising antibody was first detected in the inoculated fish at $10 \mathrm{dpi}$ and in the in-contact fish $11 \mathrm{~d}$ later. Clinical signs and microscopic lesions indistinguishable from naturally occurring pancreas disease (PD) were observed in SPDV inoculated and in-contact smolts. No lesions were detected in the negative controls. These resuits provide strong evidence that SPDV is the etiologic agent of $\mathrm{PD}$ in farmed Atlantic salmon in Ireland.
\end{abstract}

KEY WORDS: Pancreas disease $\cdot$ Experimental $\cdot$ Pathology $\cdot$ SPDV Atlantic salmon smolts

\section{INTRODUCTION}

Pancreas disease (PD) was recognised in Scotland in 1976, and the first description was published in 1984 (Munro et al. 1984). Similar disease syndromes were subsequently described on the west coast of the United States (Kent \& Elston 1987), Norway (Poppe et al. 1989), Ireland (Murphy et al. 1992) and in France and Spain (Raynard et al. 1992). Typically, PD affects farmed Atlantic salmon Salmo salar smolts during their first year at sea. Clinical signs include inappetence, sluggish swimming activity and an increase in the number of faecal casts in affected cages. Mortality rates of 10 to $50 \%$ of the yearly smolt input have been reported on Irish salmon farms (Wheatley 1994, Men-

\footnotetext{
·E-mail: mcloughm@dani.gov.uk
}

zies et al. 1996). Variable mortality levels have been attributed to PD in other countries. Up to $10 \%$ of survivors fail to grow and many die several months after the acute phase of the disease.

Descriptions of gross post-mortem findings include petechial hemorrhages in the periacinar fat, absence of food in the gut and reduced body fat. Microscopic lesions associated with this disease are exocrine pancreatic acinar necrosis (Munro et al. 1984) and cardiac and skeletal myopathies (Ferguson et al. 1986b, Rodger et al. 1991، Murphy et al. 1992, Rodger et al. 1994).

Recently a toga-like virus was isolated from PD affected Atlantic salmon smolts (Nelson et al. 1995). Hereafter the virus is referred to as salmon pancreas disease virus (SPDV) and the purpose of the present study is to describe the experimental reproduction of $\mathrm{PD}$ in Atlantic salmon post-smolts exposed to this virus. 


\section{MATERIALS AND METHODS}

Experimental transmission design. Fish: Three hundred disease-free Atlantic salmon post-smolts of mean weight $87 \mathrm{~g}$ were supplied, maintained and sampled by Marine Harvest Ltd, Lochailort, Scotland. They were kept in $2 \times 1.5 \mathrm{~m}$ tanks in ozone-sterilized sea water supplied in a flow-through system at 12 to $15^{\circ} \mathrm{C}$ and ambient salinity. Effluent water was sterilised with ozone to prevent any release of live virus. The fish were maintained for $2 \mathrm{wk}$ to acclimatise, prior to inoculation, and samples of tissues from 10 fish were cultured to check for the presence of infectious pancreatic necrosis virus (IPNV) and also examined histologically for evidence of $\mathrm{PD}$.

Inoculum 1: SPDV was purified by 3 limiting dilutions and used at 11th passage in CHSE-214 cells. A virus pool was prepared by inoculating SPDV into CHSE-214 cells at a multiplicity of infection (MOI) of 1 and harvesting after $8 \mathrm{~d}$ incubation at $15^{\circ} \mathrm{C}$. The cells were disrupted by freezing and thawing once and the cell debris was removed by centrifugation at $1000 \times g$ for $30 \mathrm{~min}$. The resultant virus pool with a titre of $10^{7} \mathrm{TCID}_{50} \mathrm{ml}^{-1}$ (Nelson et al. 1995) was filtered through a $0.22 \mu \mathrm{m}$ porosity Millipore filter. The fish were anaesthetised using benzocaine $(10 \% \mathrm{w} / \mathrm{v}$ ethyl 4 -aminobezoate in acetone) and $0.1 \mathrm{ml}$ of SPDV inoculated intraperitoneally (i.p.) into each of 100 fish. Fifty fin-clipped, un-inoculated fish were added to the tank as in-contact fish.

Inoculum 2: Controls consisted of 100 fish inoculated i.p. with a lysate from un-infected CHSE-214 cells prepared in exactly the same manner as the virus infected cells, along with 50 additional uninoculated in-contact fish.

Sampling: On $7,10,15,21,28,35$ and 42 days post inoculation (dpi), the fish were bled then killed by an overdose of benzocaine $(10 \%$ w/v ethyl 4 -aminobenzoate in acetone), and samples of heart, spleen, liver, pyloric caeca/pancreas and muscle were taken from 10 inoculated and 10 control fish for histological examination. Heart, spleen, kidney and caeca/pancreas samples were also taken from the same fish for virus isolation. At 14,21,28, 35 and 42 dpi, 5 in-contact fish were removed and tissues sampled for histology. Incontact fish were sampled for virus isolation at 14 and $21 \mathrm{dpi}$ only. All fish were weighed at sampling and clinical and gross post-mortem signs were recorded.

Histology: Samples for histological examination were fixed in $10 \%$ formaldehyde in buffered saline $\mathrm{pH} 7.0$, and embedded in paraffin wax and $5 \mu \mathrm{m}$ sections were cut on a Reichert Ultracut $\mathrm{S}$ microtome. They were stained with haematoxylin and eosin.

SPDV isolation: Tissues were prepared in mortars and pestles as 10\% homogenates in maintenance medium (MEMM) consisting of Eagle's minimum essen- tial medium containing Earle's salts and sodium bicarbonate $\left(2.2 \mathrm{~g} \mathrm{l}^{-1}\right)$, supplemented with $200 \mathrm{mM}$ L-glutamine, $1 \%$ non-essential amino acids, $0.01 \mathrm{M}$ HEPES, $500 \mathrm{IU}$ penicillin $\mathrm{ml}^{-1}, 500 \mu \mathrm{g} \mathrm{ml}^{-1}$ streptomycin sulphate, $0.625 \mathrm{\mu g} \mathrm{ml}^{-1}$ amphotericin $\mathrm{B}$ and $2 \%$ FBS (foetal bovine serum). The homogenates were centrifuged at $2500 \times \mathrm{g}$ for $15 \mathrm{~min}$ then inoculated at final dilutions of $1: 20$ and 1:100 into each of 2 wells in a 24well plate containing CHSE-214 cells and incubated at $15^{\circ} \mathrm{C}$ for $28 \mathrm{~d}$. Samples showing no cytopathic effects (CPE) were given 1 further passage into CHSE-214 cells before being considered negative.

Serological tests. SPDV neutralisation tests were carried out using the constant virus - varying serum method (Schmidt 1964). Serum dilutions of $1 / 10$ to $1 / 160$ were prepared in MEMM and an equal volume incubated with $200 \mathrm{TCID}_{50} \mathrm{SPDV}$ for $2 \mathrm{~h}$ at $15^{\circ} \mathrm{C}$. Each virus - serum dilution $(0.1 \mathrm{ml}$ per well) was inoculated into CHSE214 cells ( 2 wells each) in a 24 -well plate (Costar 3524) Control sera from fish with no previous history of PD were included as negative controls. The cultures were examined for CPE with final reading at $10 \mathrm{dpi}$ and the neutralisation titre was taken as the highest dilution of serum which neutralised $100 \mathrm{TCID}_{50}$ of virus.

\section{RESULTS}

\section{Pre-inoculation sample}

No microscopic lesions were detected in the samples taken prior to inoculation with SPDV. No viruses were isolated at this stage.

\section{Clinical signs and pathlogical lesions}

SPDV inoculated fish

By 7 dpi the majority of fish were not feeding and 2 had faecal casts in the lower intestine. Six fish had focal or diffuse pancreatic acinar cell necrosis. Necrotic acinar cells often contained numerous vacuoles in which cellular debris was evident and many of the cells had pyknotic nuclei (Fig. 1). Focal cardiomyocytic necrosis was present in both spongy and compact ventricular trabecular muscle of the same fish. Affected cardiomyocytes were stained intensely with eosin, had shrunken cytoplasm with loss of striations and pyknotic nuclei.

By $10 \mathrm{dpi}, 90 \%$ of the fish were not feeding. Petechial hemorrhages were observed in the pancreatic fat in 5 fish. Nine fish had significant pancreatic acinar cell loss. Diffuse multifocal cardiomyocytic necrosis was observed in the same 9 fish (Fig. 2). Early degener- 


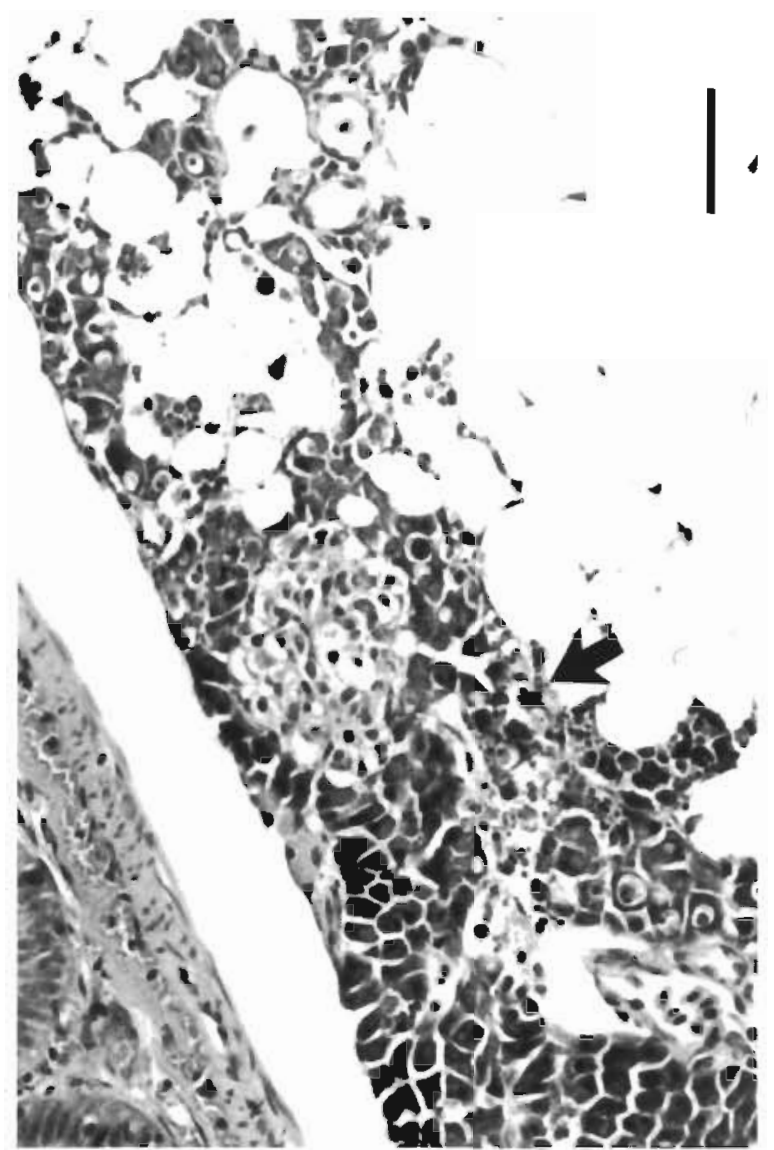

Fig. 1. SPDV infected Salmo salar. Acute pancreatic acinar cell necrosis $(\longrightarrow)$ induced in an experimentally infected fish at $7 \mathrm{dpi}$. Scale bar $=50 \mu \mathrm{m}$

ative changes were observed in small numbers of skeletal red muscle fibres in $50 \%$ of the fish. Affected myocytes were swollen and deeply eosinophilic.

At $15 \mathrm{dpi}, 7$ fish had food in the gut and 1 had petechial hemorrhages in the pancreatic fat. Nine fish had significant pancreatic acinar cell loss. Some intact pancreatic acinar cells remained around the islets of Langerhans and larger intralobular ducts. The remaining fish had focal acinar loss. All fish had diffuse multifocal cardiomyocytic necrosis as previously described. Similar lesions were inconsistently detected in the atrial myocardium throughout this study. Fifty percent of fish had mild red and white skeletal myocytic degeneration. There was an increased number of fibres undergoing degeneration and an apparent increase in endomysial connective tissue, especially around degenerating red muscle fibres. Proliferation of sarcolemmal satellite nuclei was evident and occasionally phagocytosis of the sarcoplasm was observed.

At $21 \mathrm{dpi}, 8$ fish were feeding and the majority had significant pancreatic acinar cell loss (Fig. 3). All fish showed evidence of cardiac lesions, which varied from mild cardiomyocytic necrosis to focal or diffuse endocardial cell proliferation and myocytic nuclear enlargement suggestive of compensatory hypertrophy. Eight fish had varying degrees of red and white skeletal muscle degeneration, ranging from a few individual muscle fibres (mild) which had undergone hyaline degeneration with limited invasion of macrophages to numerous damaged muscle fibres (severe), especially in the red muscle band underlying the lateral line.

At $28 \mathrm{dpi}, 9$ fish had food in the gut; $50 \%$ of fish had significant pancreatic acinar cell loss, with the remainder having focal acinar loss. The inflammatory response was variable but mild in most fish. It consisted of small numbers of monocytic inflammatory cells within the periacinar fat and mild fibroplasia. Six fish had mild focal or severe diffuse heart lesions. There was focal to diffuse endocardial cell proliferation, and an increase in the number of cardiomyocytes undergoing mitosis. The heart had an overall hypercellular appearance especially at the junction of the compact and spongy ventricular muscle (Fig. 4). Nine fish had mild to severe red and white skeletal muscle degeneration.

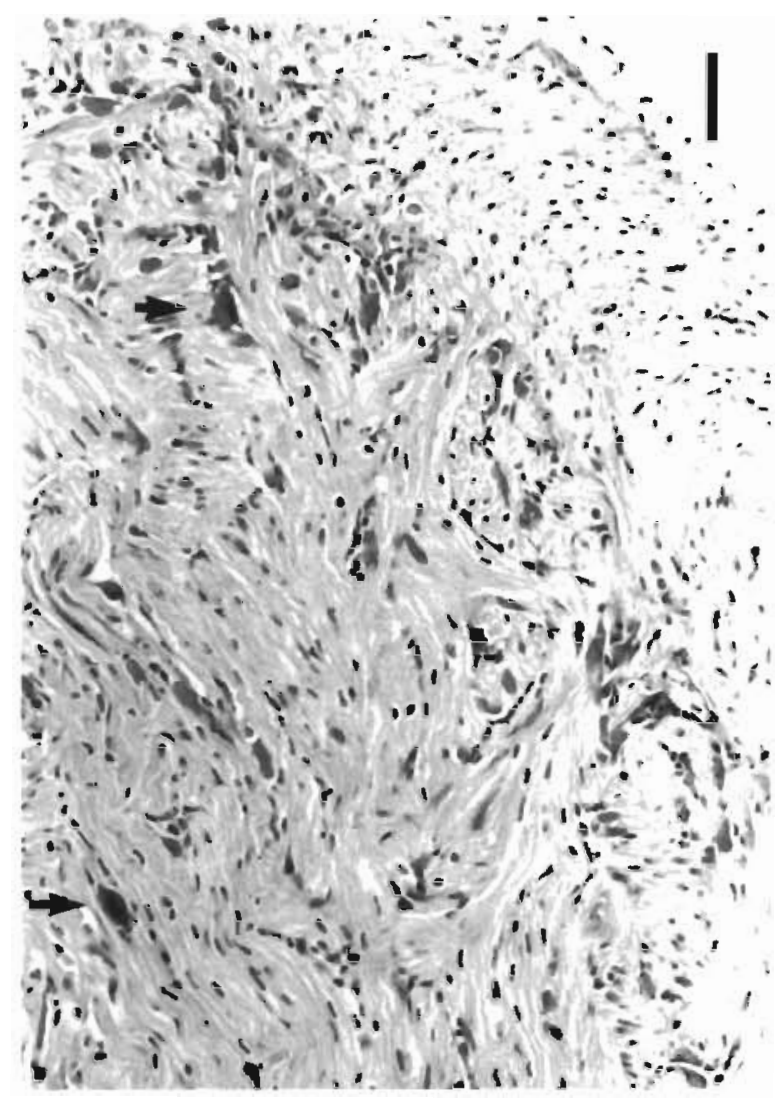

Fig. 2. SPDV infected Salmo salar. Diffuse multifocal cardiomyocytic necrosis $\rightarrow$ in experimentally infected fish at $10 \mathrm{dpi}$. Scale bar $=50 \mu \mathrm{m}$ 


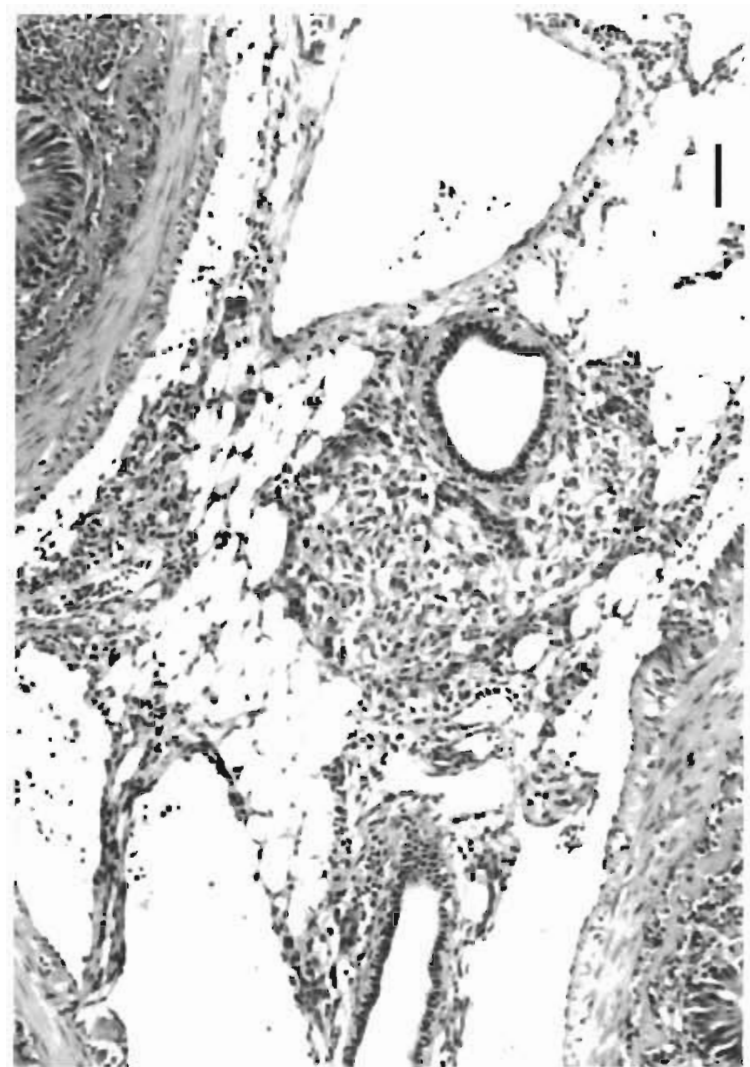

Fig. 3. SPDV infected Salmo salar. Significant pancreatic acinar cell loss typical of pancreatic lesions induced by SPDV in an experimentally infected fish at $21 \mathrm{dpi}$. Scale bar $=50 \mu \mathrm{m}$

At 35 and $42 \mathrm{dpi}$, the majority of fish had no food in the gut. Fifty percent of the fish had significant acinar cell loss, with the remainder having variable amounts of acinar tissue. The distribution ranged from small scattered acinar groups, especially at the periphery of the pancreatic fat, to a relatively normal acinar cell pattern with little evidence of acinar cell loss. No significant inflammatory reaction or fibroplasia was noted. The heart lesions in 5 fish were similar to those on Day 28. Mild to severe red and white skeletal muscle degeneration was detected in all fish (Fig. 5)

No significant lesions were detected in any other tissues examined. No fish died during the transmission study.

\section{In-contact fish}

At $14 \mathrm{dpi}, 4$ fish were not feeding and had diffuse pancreatic acinar cell necrosis, with concurrent multifocal cardiomyocytic necrosis detected in 3 fish. By $21 \mathrm{dpi}$ none of the fish were feeding and all had signif- icant acinar loss as well as diffuse cardiomyocytic necrosis with early mild red and white skeletal muscle degeneration. $\wedge$ t 28 dpi 3 fish were not fecding, 1 fish had petechial haemorrhages in the periacinar fat, all of the fish had focal or significant acinar cell loss (Figs. $6 \& 7$ ) and 4 had typical cardiac lesions. All had small numbers of degenerating red and white muscle fibres. At 35 and 42 dpi the majority of the fish were not feeding and some had faecal casts in the gut. Nine of the 10 fish had significant acinar loss. They had focal endocardial cell proliferation and hypercellular appearance of the junction of the compact and spongy muscle layers. All fish had varying degrees of red and white muscle degeneration (Fig. 8).

\section{Inoculum 2}

No clinical signs or microscopic lesions were detected in any of the control fish.

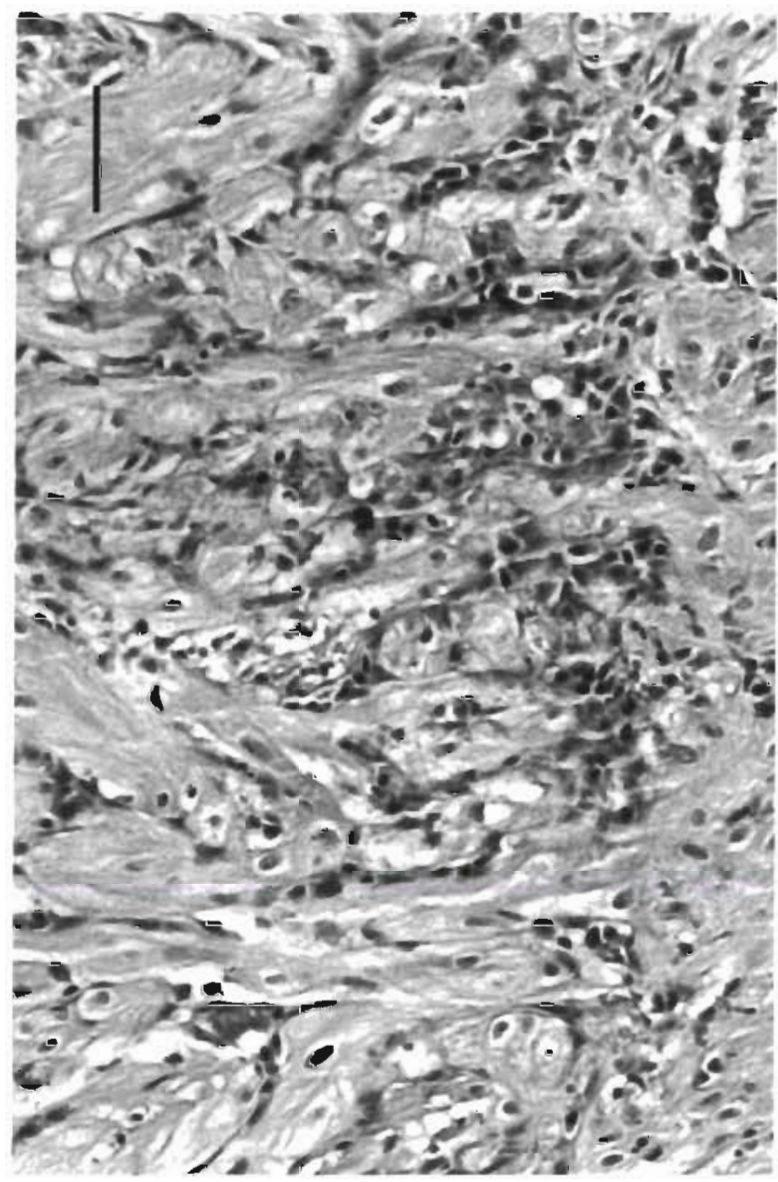

Fig. 4. SPDV infected Salmo salar. Endocardial cell proliferation and mononuclear cell infiltration at the junction of the compact and spongy cardiac ventricular muscle in experimentally infected fish at 28 dipi. Scale bar $=50 \mu \mathrm{m}$ 


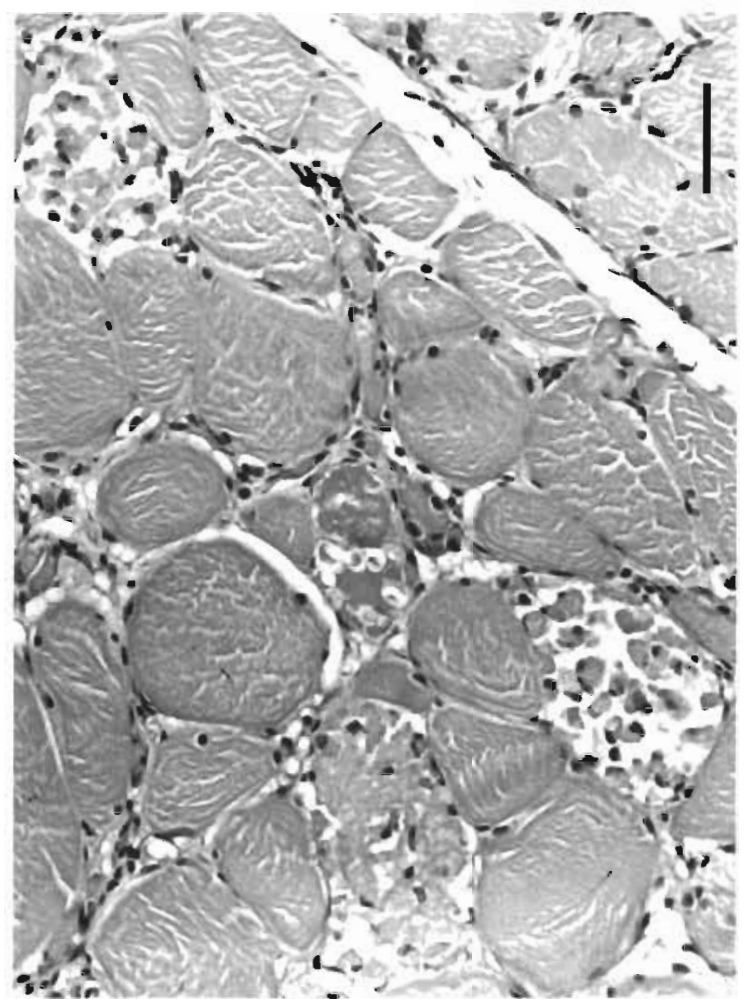

Fig. 5. SPDV infected Salmo salar. Hyaline degeneration of anaerobic (white) skeletal muscle fibres showing phagocytosis of fibre contents at $42 \mathrm{dp}$. Scale bar $=50 \mu \mathrm{m}$.

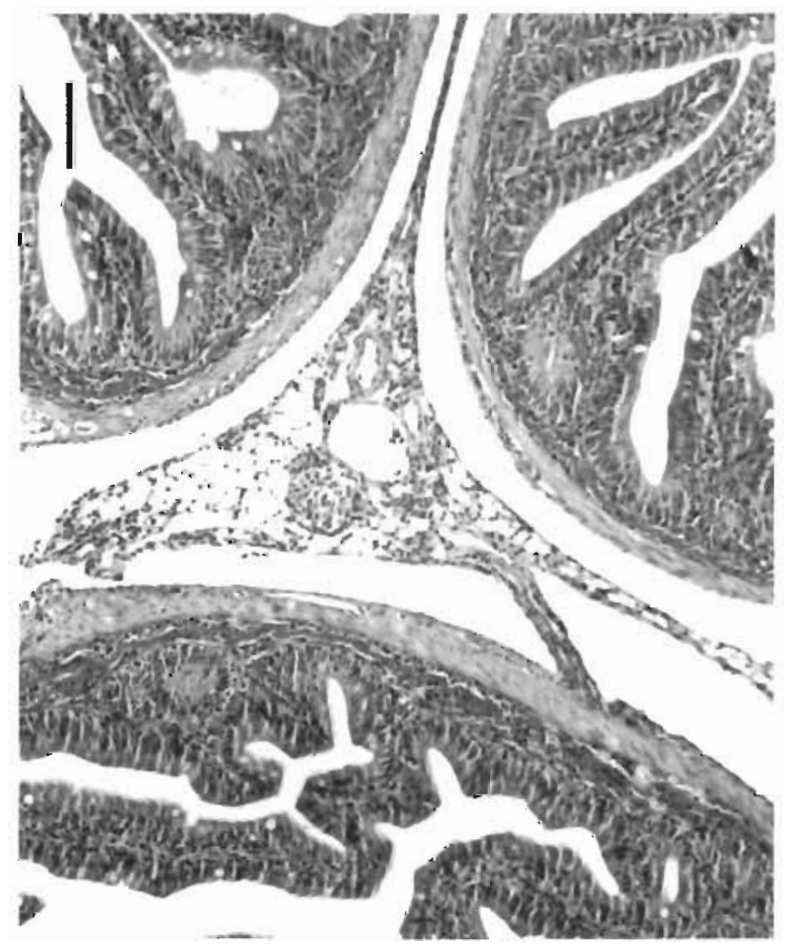

Fig. 6. In-contact Salmo salar. Significant pancreatic cell loss typical of pancreatic lesions observed in cohabitant fish at $28 \mathrm{dpi}$. Scale bar $=1.00 \mu \mathrm{m}$

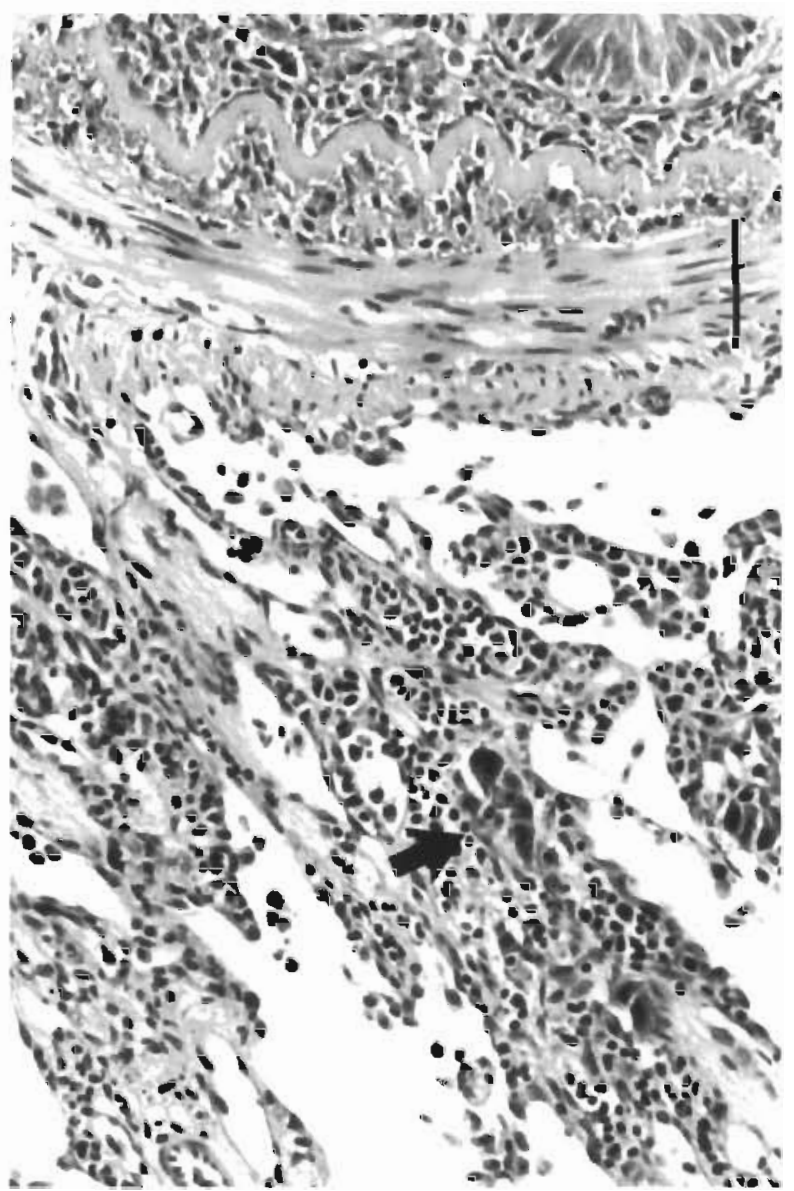

Fig. 7 In-contact Salmo salar. Exocrine pancreas showing significant infiltration of periacinar fat with mononuclear inflammatory cells. A few pancreatic acinar cells remain $(\overrightarrow{)}$ in cohabitant fish $21 \mathrm{dpi}$. Scale bar $=50 \mu \mathrm{m}$

\section{Virus isolation}

Virus was isolated from fish inoculated with SPDV and in-contact fish from the same tank but not from any of the control fish (Table 1). No IPNV was detected at any stage in the transmission study.

Table 1. Virus isolations from Atlantic salmon Salmo salar used in transmission experiment. Values presented as no. of positive fish/no. of fish examined. nd: not done

\begin{tabular}{|lccccccc|}
\hline Fish group & \multicolumn{8}{c|}{ Days post-inoculation } \\
& 7 & 10 & 14 & 15 & 21 & 28 \\
\hline Controls $^{\text {a }}$ & $0 / 10$ & $0 / 10$ & nd & $0 / 10$ & $0 / 10$ & $0 / 10$ \\
Virus-inoculated & $7 / 10$ & $8 / 10$ & nd & $10 / 10$ & $3 / 10$ & nd \\
In-tank contacts & nd & nd & $5 / 5$ & nd & $5 / 5$ & nd \\
anoculated with CHSE-214 cell lysate & & & \\
all & & & & & \\
\end{tabular}




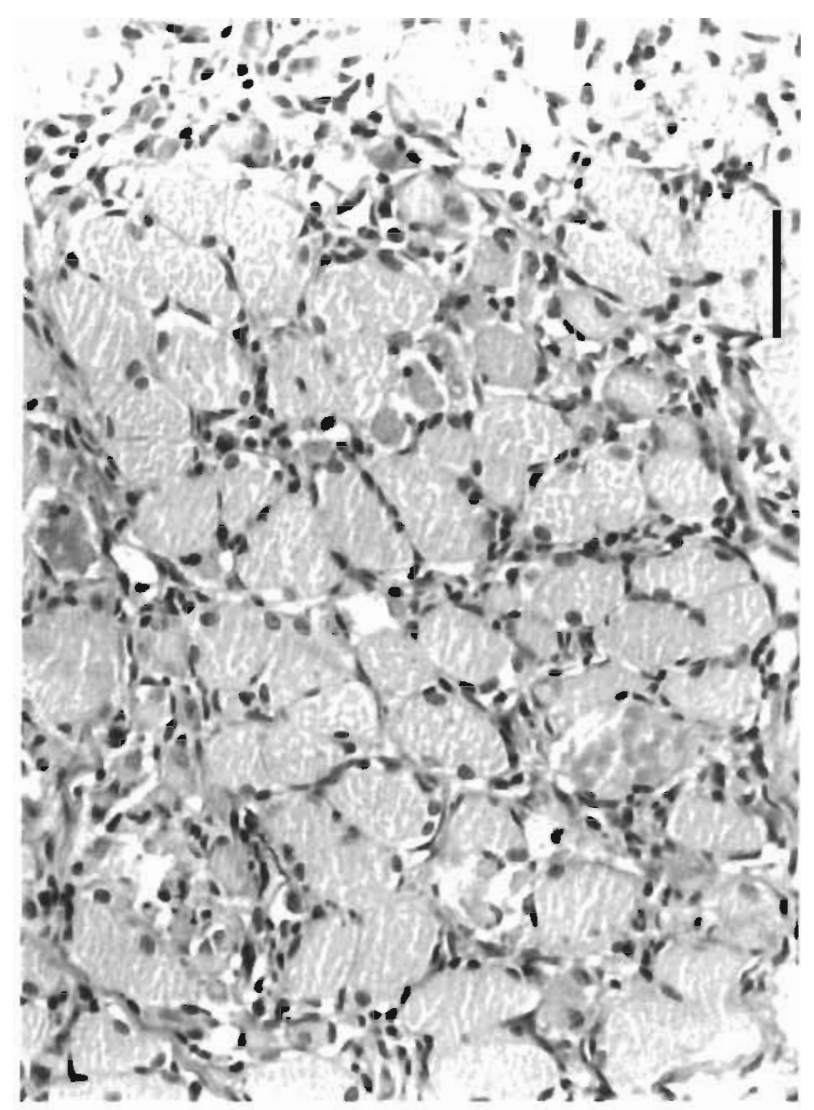

Fig. 8. In-contact Salmo salar. Degeneration of aerobic (red) skeletal muscle showing proliferation of sarcolemmal cells and early hyaline degeneration. Scale bar $=50 \mu \mathrm{m}$

\section{Serological tests}

Neutralising antibody to SPDV was first detected in 4 out of 10 inoculated fish by $10 \mathrm{dpi}$ and all sampled fish had antibody by Day 21 (Table 2). Antibody in the in-contact fish was first detected $11 \mathrm{~d}$ later than in the inoculated fish (Table 3). Antibody titres in individual fish of both groups varied but they

Table 2. Serum neutralisation titres in Salmo salar at each sampling point post inoculation with SPDV. $\mathrm{n}=10$ fish

\begin{tabular}{|ccccccccc|}
\hline $\begin{array}{c}\text { Days post } \\
\text { inoculation }\end{array}$ & $<1 / 20$ & $1 / 20$ & $1 / 40$ & $1 / 80$ & $1 / 160$ & $1 / 320$ & $\begin{array}{c}\text { Median } \\
\text { values }\end{array}$ \\
\hline 0 & 10 & - & - & - & - & - & $<1 / 20$ \\
7 & 10 & - & - & - & - & - & $<1 / 20$ \\
10 & 6 & 4 & - & - & - & - & $<1 / 20$ \\
14 & 4 & 6 & - & - & - & - & $1 / 20$ \\
21 & - & - & 3 & 3 & 4 & - & $1 / 80$ \\
28 & - & - & 2 & 6 & 2 & - & $1 / 80$ \\
35 & - & - & 3 & 5 & 2 & - & $1 / 80$ \\
42 & - & - & - & 4 & 6 & - & $1 / 160$ \\
& & & & & & & \\
\hline
\end{tabular}

showed an overall increase to 42 dpi when the experiment finished. No neutralisation was observed in the pre-inoculation sera or in the control sera.

\section{DISCUSSION}

Our transmission study has confirmed that the inoculation of SPDV causes disease in seawater salmon smolts that is clinically and pathologically indistinguishable from published descriptions of field outbreaks of PD (Munro et al. 1984, Ferguson et al. 1986a, b, McVicar 1987, 1990, Murphy et al. 1992). While controversy exists as to the severity and tissue distribution of histopathological lesions associated with 'classical' PD (Wheatley 1994), our findings are in close agreement with the descriptions of Ferguson et al. (1986a, b) and Rodger et al. (1994) of outbreaks of PD in Scotland and Murphy et al. (1992) who described the sequential pathology of 2 PD outbreaks in Ireland.

The lesions observed in the current transmission studies represent the full range of acute and chronic pancreatic, cardiac and skeletal muscle lesions as observed by us in field outbreaks of PD and described by other workers. In the initial descriptions of pancreas disease, Munro et al. (1984) and McVicar (1987) reported consistent lesions in the pancreas only. McVicar (1987) imposed exacting histological criteria for the diagnosis of PD, stating that total loss of exocrine acinar tissue was indicative of $\mathrm{PD}$. This criterion continued to be used by some workers in the interpretation of experimentally induced PD using inocula of tissue homogenates from PD affected smolts (Raynard et al. 1991, Pringle et al. 1992, Raynard \& Houghton 1993, Houghton 1994). Our experience with experimentally induced PD using both infected tissue homogenates (McLoughlin et al. 1995) and the SPDV isolate is that not all fish suffer total acinar loss, which probably represents the extreme end of the pancreatic lesion spectrum. Many of the fish sampled $6 \mathrm{wk}$ after inoculation had significant amounts of acinar tissue in the sections examined. It was not possible to determine whether or not this acinar tissue resulted from regeneration of pancreatic acini or if the tissue had survived viral attack. This requires further investigation.

Early descriptions of PD suggested that lesions in other tissues were sporadic and not a major feature of the PD syndrome (Munro et al. 1984, McVicar 1987). However there is increasing evidence that cardiac lesions are consistently found in field outbreaks of PD (Ferguson et al. 1986b, Rodger et al. 1991, Murphy et al. 1992, 
Table 3. Serum neutralisation titres of in-contact Salmo salar at each sampling point. $\mathrm{n}=10 \mathrm{fish}$

\begin{tabular}{|c|c|c|c|c|c|c|c|}
\hline \multirow{2}{*}{$\begin{array}{l}\text { Sampling } \\
\text { point }\end{array}$} & \multicolumn{6}{|c|}{ Neutralising antibody titres } & \multirow{2}{*}{$\begin{array}{l}\text { Mediar } \\
\text { value }\end{array}$} \\
\hline & $<1 / 20$ & $1 / 20$ & $1 / 40$ & $1 / 80$ & $1 / 160$ & $1 / 320$ & \\
\hline Day 15 & 5 & - & - & - & - & - & $<1 / 20$ \\
\hline Day 21 & 3 & 1 & 1 & - & - & - & $<1 / 20$ \\
\hline Day 28 & 2 & - & 1 & 1 & 1 & - & $1 / 40$ \\
\hline Day 35 & - & - & 2 & 2 & 1 & - & $1 / 80$ \\
\hline Day 42 & - & - & 1 & 3 & 1 & - & $1 / 80$ \\
\hline
\end{tabular}

Rodger et al. 1994). Diffuse cardiomyocytic necrosis was first reported in experimentally induced PD by McLoughlin et al. (1995) in freshwater salmon parr inoculated with tissue homogenates from PD-affected fish. The current study confirmed the presence of multifocal cardiomyocytic necrosis in sea-water salmon smolts similar to the cardiac lesions described in field and experimental PD

Significant skeletal myopathies have been associated with naturally occurring PD outbreaks (Ferguson et al. 1986a, b. Rodger et al. 1991, Murphy et al. 1992, Rodger et al. 1994). Skeletal muscle lesions have not previously been reported in experimentally induced PD. The skeletal muscle lesions observed in this study occurred at approximately 2 to $3 \mathrm{wk}$ pi. They were identical in appearance but not as severe as those reported in descriptions of naturally occurring $\mathrm{PD}$ outbreaks. This may be due to the reduced water flow in the experimental tanks compared to the more demanding water conditions in sea cages. These conditions may influence the rate of development and recovery of the skeletal muscle lesions. Investigations into the clinical biochemistry of skeletal muscle lesions occurring during PD outbreaks suggested that low plasma and tissue vitamin E levels in affected fish may be involved in the pathogenesis of the skeletal muscle lesions (Ferguson et al. 1986a, Rodger et al. 1991). Recent studies in Irish salmon by McCoy et al. (1994) revealed that despite high plasma and tissue vitamin $E$ levels, PD-affected fish still developed significant red and white skeletal muscle lesions. These findings suggest that the skeletal lesions are not due to an absolute vitamin E deficiency at tissue level. Roy (1991) recorded a similar picture in Scottish farms, with plasma vitamin $E$ concentrations remaining fairly constant before, during and after a PD outbreak. Either absorption of dietary vitamin $\mathrm{E}$ continues (i.e. fat absorption continues) during clinical PD or, more likely, plasma vitamin $\mathrm{E}$ concentrations are maintained by rapid mobilization of vitamin E from storage organs, primarily the liver. Again the pathogenesis of the observed skeletal muscle lesions in both naturally occurring and induced PD requires further investigation.
In-contact fish developed similar clinical signs and microscopic lesions 1 wh later than the experimentally infected fish, indicating that SPDV can cause disease via natural exposure. An estimated incubation period of 7 to $14 \mathrm{~d}$ at water temperatures of 12 to $15^{\circ} \mathrm{C}$ was recorded and is useful information in understanding the natural spread of PD on farms.

No mortalities were recorded in this study, possibly due to the muscle damage being less severe than that normally observed in naturally occurring $\mathrm{PD}$ and the relatively stress-free environment of the experimental tanks.

Neutralising antibody to SPDV was first detected in the affected fish $10 \mathrm{~d}$ after inoculation and in the incontact fish 11 d later. Antibady titres increased until the end of the experiment at $6 \mathrm{wk}$ pi.

This is the first report of the experimental induction of pancreas disease in which concurrent pancreatic, cardiac and subsequent skeletal muscle lesions have been described. The reproduction of PD in smolts following i.p. inoculation of and in-contact exposure to SPDV, as well as its re-isolation from the fish, provides strong evidence that this virus is the aetiological agent of $P D$ in farmed Atlantic salmon and justifies naming the virus salmon pancreas disease virus, SPDV.

This reproducible experimental model of PD will enable testing of the protection conferred by vaccines developed from this virus. The isolation of the virus will also enable the development of antigen detection systems which will assist in the rapid diagnosis of $\mathrm{PD}$. Furthermore, it will allow full investigation of the pathogenesis and epidemiology of this important disease of Atlantic salmon.

Acknowledgements. The authors thank Michael Platten, Joyce McCormick and David Maginnes of the Fish Diseases Unit for their technical support, Cliff Mason of the Photography unit, Veterinary Sciences Division, for assistance with the photomicrographs, and Simon Wadsworth and the staff of the R\&D department of Marine Harvest McConnell, at Lochailort, for their excellent technical assistance. Aspects of this work are subject to patent applications.

\section{LITERATURE CITED}

Ferguson HW, Rice DA, Lynas JK (1986a) Clinical pathology of myodegeneration (pancreas disease) in Atlantic salmon (Salmo salar). Vet Rec 119:297-299

Ferguson HW, Roberts RJ, Richards RH, Collins RO, Rice DA (1986b) Severe degenerative cardiomyopathy associated with pancreas disease in Atlantic salmon (Salmo salar). J Fish Dis 9:95-98

Houghton G (1994) Acquired protection in Atlantic salmon Salmo salar parr and post-smolts against pancreas disease. Dis Aquat Org 18:109-118 
Kent ML, Elston RA (1987) Pancreas disease in pen-reared Atlantic salmon in North America. Bull Eur Ass Fish Pathol 7:29-31

McCoy MA, McLoughlin MF, Rice DA, Kennedy DG (1994) Pancreas disease in Atlantic salmon (Salmo salar) and vitamin E supplementation. Comp Biochem Physiol 109A: 905-912

McLoughlin MF, Nelson RT, McCormick JI, Rowley H (1995) Pathology of experimental pancreas disease in freshwater Atlantic salmon (Salmo salar) parr. J Aquat Anim Health 7 . $104-110$

McVicar AH (1987) Pancreas disease of farmed Atlantic salmon, Salmo salar, in Scotland: epidemiology and early pathology. Aquaculture 67:71-78

McVicar AH (1990) Infection as a primary cause of pancreas disease in farmed Atlantic salmon. Bull Eur Ass Fish Pathol 10:84-87

Menzies FD, Wheatley SB, Goodall EA, McLoughlin MF (1996) Develupnent of d curiputensed inforination retrieval system for Atlantic salmon (Salmo salar). Aquacult Res 27:183-190

Munro ALS, Ellis AE, McVicar AH, McLay HA (1984) An exocrine pancreas disease of farmed Atlantic salmon in Scotland. Helgol Meeresunters 37:571-586

Murphy TM, Rodger HD, Drinan EM, Gannon F, Kruse P, Körting $W(1992)$ The sequential pathology of pancreas disease in Atlantic salmon farms in Ireland. J Fish Dis 15:401-408

Nelson RT, Mcloughlin MF, Rowley HM. Platten MA, McCormick JI (1995) Isolation of a toga-like virus from farmed Atlantic salmon Salmo salar with pancreas disease. Dis Aquat Org 22:25-32

Poppe T, Rimstad E, Hyllseth B (1989) Pancreas disease in Atlantic salmon (Salmo salar) post smolts infected with infectious pancreatic necrosis (IPNV). Bull Eur Ass Fish Pathol 9:83-85

Responsible Subject Editor: F. M. Hetrick, College Park, Maryland, USA
Pringle GM, Houlihan DF, Callanan KR, Mitchell AI, Raynard RS, Houghton G (1992) Digestive enzyme levels and histopathology of pancreas disease in farmed Atlantic salmon (Salmo salar). Comp Biochem Physiol 102A:759-768

Raynard RS, McVicar AH, Bell JG, Youngson A, Knox D, Fraser CO (1991) Nutritional aspects of pancreas disease of Atlantic salmon; the effects of dietary Vitamin $E$ and polyunsaturated fatty acids. Comp Biochem Physiol 98A: 125-131

Raynard R, Houghton G, Munro ALS (1992) Pancreas disease of Atlantic salmon: proceedings of a European Commission Workshop. Scottish Office Aquaculture Report, The Scottish Office Agriculture and Fisheries Department, Aberdeen, No. 1, p 2-4

Raynard RS, Houghton G (1993) Development towards an experimental protocol for the transmission of pancreas disease of Atlantic salmon Salmo salar. Dis Aquat Org 15: $123-128$

Rodger rD, Murphy TAM, Drinon EMA, Rico DA (19g1) Acute skeletal myopathy in farmed Atlantic salmon (Salmo salar). Dis Aquat Org 12:17-23

Rodger HD, Turnbull T, Richards RH (1994) Myopathy and pancreas disease in salmon: a retrospective study in Scotland. Vet Rec 135:234-235

Roy WJ (1991) Vitamin E nutrition and pancreas disease in farmed Atlantic salmon (Salmo salar L.). PhD thesis, Institute of Aquaculture, University of Stirling

Schmidt NJ (1964) Tissue culture methods and procedures for diagnostic virology. In: Lennette EH, Schmidt NJ (eds) Diagnostic procedures for viral and rickettsial diseases, Chap 3. American Public Health Assoc, Inc, New York, p $120-123$

Wheatley SB (1994) Epidemiological investigations of Atlantic salmon production using a computerised database system PhD thesis, Queen's University, Belfast

Manuscript first received: August 1, 1995

Revised version accepted: February 9,1996 